Indonesian Journal of Biotechnology, June, 2013

Vol. 18, No. 1, pp.1-7

\title{
Partial Purification, Stability Analysis, and Preservation of Xylanase from Xylanolytic Alkalophylic Bacteria
}

\author{
Chusnul Hanim ${ }^{1 *}$, Muhamad Nur Cahyanto ${ }^{2}$, Lies Mira Yusiati ${ }^{1}$, and Ali Wibowo ${ }^{1}$
}

${ }^{1}$ Faculty of Animal Science, Universitas Gadjah Mada, Yogyakarta, Indonesia

${ }^{2}$ Faculty of Agricultural Technology, Universitas Gadjah Mada, Yogyakarta, Indonesia

\begin{abstract}
Abtsract
A xylanase, which produces xylose from oat spelt xylans, was isolated from the culture medium of xylanolytic alkalophylic bacteria mutant. The enzyme was purified by ammonium sulphate with level 30, 40, $50,60,70,80$, and $90 \%$. The purify of the final preparation was demonstrated by sodium dodecyl sulphatepolyacrylamide gel electrophoresis. The molecular masses of the purified xylanase were 137.61 and 165.34 $\mathrm{kDa}$. Result of ammonium sulphate saturation with the highest activity was used as standart for saturation for enzyme production and preservation, using corn, tapioca, soy bean meal and gaplek flour as carriers. Addition of $60 \%$ ammonium sulphate showed the highest xylanase activity $(62.03 \mathrm{U} / \mathrm{g})$, and produced $89.40 \%$ enzyme recovery. Tapioca, as a carrier, produced the highest xylanase activity.
\end{abstract}

Key words: preservation, purification, stability analysis, xylanase.

\section{Introduction}

The plant cell wall is a complex composite of structural polysaccharides that represents the most abundant source of organic molecules in the biosphere. The annual recycling of 1011 tons of plant structural polysaccharides is an important biological process that is integral to the carbon cycle (Taylor et al., 2006). The catabolic breakdown of hemicellulose thus represents a critical step in the recycling of carbon in nature and has been targeted as a subject of intense research with respect to renewable energy resources. $\beta$-1,4-linked xylopyranose is the principal component of plant cell wall hemicellulose, which represents the second largest reservoir of fixed carbon in the biosphere (Dodd et al., 2009). Hemicelluloses are a complex heteropolymer made up of glucoronoxylans, arabinoxylans,

*Corresponding author:

Chusnul Hanim

Faculty of Animal Science Universitas Gadjah Mada, Yogyakarta, Indonesia

e-mail: c.hanim@ugm.ac.id, Phone: 62-8164222369 glucomannans, arabinogalactans and galactomannans (Singh et al.,2007). Xylan is the most abundant renewable polysaccharide after cellulose (Gupta and Kar, 2009) and as a major component of hemicellulose contributing $15-30 \%$ of the total dry weight in angiosperm an $7-12 \%$ in gymnosperm. The backbone of xylan consists of $\beta-1,4-x y l o p y r a n o s y l$ residues (Singh et al., 2007), depending on the plant source, can be variably substituted by side chains of arabinosyl, glucuronosyl, ethylglucuronosyl, acetyl, feruloyl and p-coumaroyl residues (Pastor et al., 2007). Xylanases are glycosidase, which hydrolyze the endo- $\beta-1,4$-xylopyranosyl linkages and degrade xylan into xylooligosaccharides. They are the key enzymes for xylan degradation and differ in their specificities toward the xylan polymer (Pastor et al., 2007). Due to its heterogenecity and complexity, the complete hydolysis of xylan requires a large variety of cooperatively acting enzymes. Endo-1,4$\beta$-D-xylanase (EC.3.2.1.8) randomly cleaves the xylan back bone at $\beta-1,4$-xylopyranosyl linkages and releases xyooligosaccharides while $\beta$-D-xylosidase (EC.3.2.1.37) cleave the 
terminal $\beta$-1,4-xylosidic linkage and releases xylose monomers from the reducing end of xylooligosaccharides and xylobiose (Singh et al, 2007; Dodd and Cann, 2009).

There is an increasing trend towards using enzymes for catalyzing biotransformations (Dalal et al., 2007). Due to their biotechnology application in various industrial processes, xylanase from microorganism have attracted increasing attention in the last decade. Their applications include biopulping wood and pulp bleaching, wastewater treatment, treating animal feed to incease digestibility, processing food to increase clarification, pretreatment of forage crop converting lignocellulosic substances into feedtocks and fuels, improve cell wall maceration for the production of plant prototypalsts. Purification has become a necessity as it leads to reduction in bulk, concentration enrichment, removal of specific impurities (e.g. toxins from therapeutic products), prevention of catalysis other than the type desired (as with enzymes), prevention of catalyst poisoning (as with enzymes), recommended product specification (e.g. pharmacopocia requirement), enhancement of protein stability and reduction of protein degradation (e.g. by proteolysis). Most of the purification methods, which are used in laboratory research, can be scaled up to industrial processes. Such methods are filtration, centrifugation, microfiltration, ultrafiltration, diafiltration, precipitation, ion-exchange chromatography and gel filtration. Ammonium sulphate precipitation is an efficient method for removal of lower molecular mass xylanases (Kuhar et al., 2007)

Selected strain from the xylanolytic alkalophylic mutan has been shown to be producer of an active xylan degradation enzyme. Previously, we have isolated the xylanolytic alkalophylic bacteria from the crabs and mutation them by ethyl methanesulfonat. The present article reports the purification and preservation of xylanase obtained from liquid state culture of xylanolytic mutan when grown on medium containing xylans from oat spelt and xylose as substrates.

\section{Materials and Methods \\ Microorganism and culture conditions}

The xylanolytic mutan used in this investigation were obtained from crabs (Eriocheir sinensis) from previous study as reported by Hanim et al. (2013). For xylanase production, the bacterium was grown on a medium containing oat spelt xylan $1 \%$ and xylose $0.02 \%$ as carbon source, supplemented with $\left(\mathrm{NH}_{4}\right)_{2} \mathrm{SO}_{4} 1 \mathrm{~g} ; \mathrm{MgSO}_{4} .7 \mathrm{H}_{2} \mathrm{O}, 0.1 \mathrm{~g}$; $\mathrm{NaCl}, 2 \mathrm{~g} ; \mathrm{K}_{2} \mathrm{HPO}_{4}, 7 \mathrm{~g}$; resazurin, $0,1 \%$; yeast extract, $1 \mathrm{~g}$; cystein $\mathrm{HCl}, 0,5 \%$ and $\mathrm{dH}_{2} \mathrm{O}$, $1.000 \mathrm{ml}$ (Omelianski (1902) cit. Skinner (1971) at $\mathrm{pH} 9.5$. The cultivation was carried out for 5 days at $35^{\circ} \mathrm{C}$.

\section{Xylanase assay}

Xylanase activity was assayed by measuring the amount of reducing sugar liberated from enzymatic hydrolysis of soluble oat spelt xylan. Briefly, assays containing $0.4 \mathrm{ml}$ of 50 $\mathrm{mM}$ sodium acetate buffer $(\mathrm{pH} 6.0)$ with 0.2 $\mathrm{ml}$ of $4 \%$ soluble oat spelt xylan, and $0.2 \mathrm{ml}$ of enzyme preparation were incubated at $50^{\circ} \mathrm{C}$ for 20 min (Ruiz - Arribas et al., 1995), after which the amount of reducing sugar was measured by the Nelson-Somogyi method with D-xylose as the standard (Plummer, 1978). Substrat and enzyme controls were always used. All assays were performed in duplicate. One unit of activity is defined as the amount of xylanase needed to liberate 1 $\mu \mathrm{mol}$ of D-xylose per min under these assay condition (Ruiz-Arribas et al., 1995).

\section{Protein measurement}

The protein concentration of the enzyme preparation was measured by Lowry method (Plummer, 1978), with bovine serum albumin as the standard.

\section{Enzyme purification}

Xylanase was purified from 1.51 of a culture supernatant. The cell-free culture supernatant, as a crude enzyme, was 
extracted by centrifugation $(14,000 \times \mathrm{g}$ for $20 \mathrm{~min}, 5^{\circ} \mathrm{C}$ ), and devided into 7 tubes (each $50 \mathrm{ml}$ ). Enzyme was partially purified by ammonium sulphate (30-90\% saturation) precipitation. After incubating overnight at $4^{\circ} \mathrm{C}$, the precipitate was discarded by centrifugation $\left(3,000 \times \mathrm{g}\right.$ for $\left.20 \mathrm{~min}, 5^{\circ} \mathrm{C}\right)$, and followed by dialysis (dialysis tubing $22 \mathrm{kDa}$ molecular weight-cutoff membranes) that performed against $10 \mathrm{mM}$ sodium acetate buffer ( $\mathrm{pH}$ 6.0). The dialysat was determined xylanase activity. The level of ammonium sulphate that gave the highest activity was carried out to enzyme production, and then it was measured the molecular mass and preserved with various carriers.

\section{Molecular mass estimation}

The molecular mass of xylanase was estimated by $12 \%$ SDS-PAGE. Proteins were stained with Coomassie brilliant blue, and PageRuler Unstained Protein Ladder was used as molecular mass marker.

\section{pH and thermal stability analysis}

For $\mathrm{pH}$ stability determination, partially purified enzymes were incubated in buffers of varying $\mathrm{pH}$ (sodium acetate buffer for $\mathrm{pH}$ 3.0-6.0, sodium phosphate buffer for $\mathrm{pH}$ 6.5-7.5) at room temperature and for 1 h. For thermal stability characterization, various temperature $\left(30-60^{\circ} \mathrm{C}\right)$ were used at sodium acetate buffer ph 6 for $1 \mathrm{~h}$. The residual xylanase activity was assayed under standard conditions.

\section{Enzyme preservation}

Xylanase was preserved with various carriers (tapioca, corn, gaplek and soy bean meal), and freeze-dried. Each treatments were determined for xylanase activity.

\section{Statistical methods}

Treatments were arranged in a one way design, with the main factors being kinds of carrier (tapioca, corn, gaplek and soy bean). The data in the main study were analyzed as a one way arrangement. The differences of mean value were analyzed by Duncan's new multiple range test (Rosner, 1990).

\section{Results}

\section{Enzyme purification}

The xylanase was tested for the effect of level of ammonium sulphate on the activity (Figure 1). Precipitation with $60 \%$ of ammonium sulphate was optimum level that result the highest activity $(62.03 \mathrm{U} / \mathrm{g})$. After the enzyme was precipitated with $50 \%$ of ammonium sulphate, $38 \%$ of the activity was retained. Thirty seven percent of the activity remained after the enzyme was precipitated with $70 \%$ of ammonium sulphate. Rapid inactivation of enzyme activity was observed bellow and above those level.

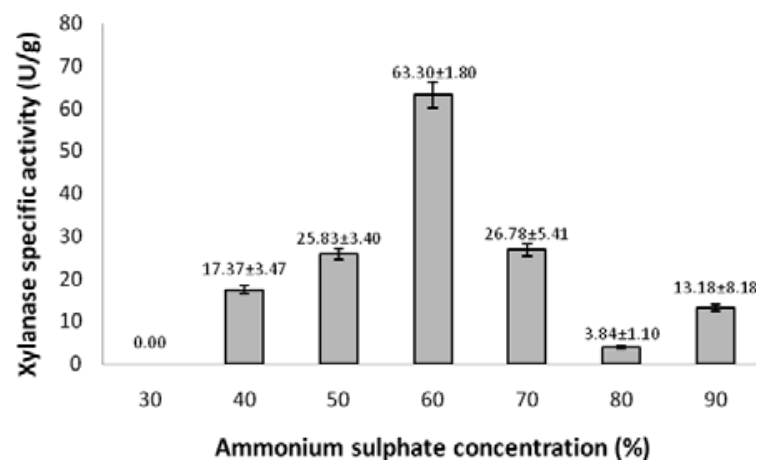

Figure 1. The effect of ammonium sulphate precipitation on enzyme activity $(\mathrm{U} / \mathrm{g})$

The xylanase was purified with $60 \%$ of ammonium sulphate to apparent homogenity. Two protein bands were seen after Coomasie brilliant blue staining, and

Table 1. Purification chart of xylanase from xylanolytic alkalophylic bacteria

\begin{tabular}{lccccc}
\hline \multicolumn{1}{c}{ Purififcation Step } & Total protein $(\mathrm{g})$ & $\begin{array}{c}\text { Total activity } \\
(\mathrm{U})\end{array}$ & $\begin{array}{c}\text { Specific activity } \\
(\mathrm{U} / \mathrm{g})\end{array}$ & $\begin{array}{c}\text { Purification } \\
(\text { fold })\end{array}$ & $\begin{array}{c}\text { Recovery } \\
(\%)\end{array}$ \\
\hline Culture supernatant & 0.290 & 1.18 & 19.66 & 1.00 & 100.00 \\
Ammonium sulphate & 0.045 & 1.05 & 62.03 & 3.15 & 89.40 \\
$(60 \%)$ fraction & & & & & \\
\hline
\end{tabular}




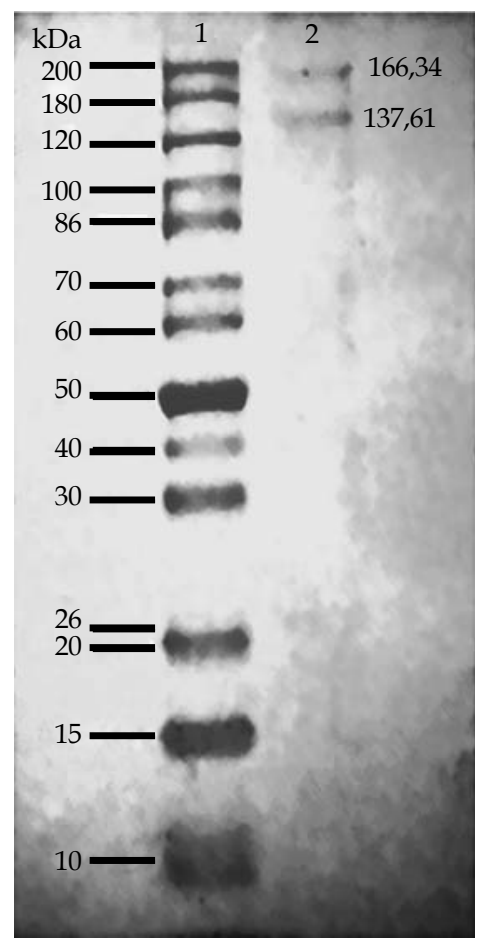

Figure 2. SDS-PAGE analysis of xylanase from alkalophylic xylanolytic bacteria. Gels were loaded with molecular mass marker (lane 1), and protein after precipitation with $60 \%$ of ammonium sulphate (lane 2)

had mass of 137.61 and $165.34 \mathrm{kDa}$ on SDSPAGE (Figure 2). Specific activity (62.03 U/g) of the purified protein was higher than that crude enzyme (19.66 U/g), as presented in Table 1. It increased 3.15-fold during this step, and resulting $89.40 \%$ of enzyme recovery. This purification procedure led to the recovery of $0.045 \mathrm{~g}$ of xylanase protein per liter of culture with a specific xylanase activity of $62.03 \mathrm{U} / \mathrm{g}$ of protein.

\section{Stability analysis of enzyme}

Analysis of the effect of $\mathrm{pH}$ and temperature on the hydrolytic activity of xylanase on oat spelt xylan showed similar $\mathrm{pH}$ and temperature profiles (Figure 3 and 4). Analysis of the influence of $\mathrm{pH}$ on enzyme stability showed that while the enzyme retained more than $80 \%$ of its initial activity after incubation at room temperature for $1 \mathrm{~h}$ in buffers ranging from $\mathrm{pH} 3.0$ to 7.5 , the enzyme was less stable under these conditions, losing more than $50 \%$ of its initial activity in buffers at $\mathrm{pH}$ lower than 3.5 or higher than 7.0. Thermostability assays showed that the enzyme remained highly stable at 35 to $40^{\circ} \mathrm{C}$ after $1 \mathrm{~h}$ of incubation at $\mathrm{pH}$ 6.0, while it lost $30 \%$ of its initial activity after incubation more than $40^{\circ} \mathrm{C}$.

\section{Enzyme preservation}

The purified enzyme was tested for the effect of kind of carriers on the activity. The activity of this enzyme was highest

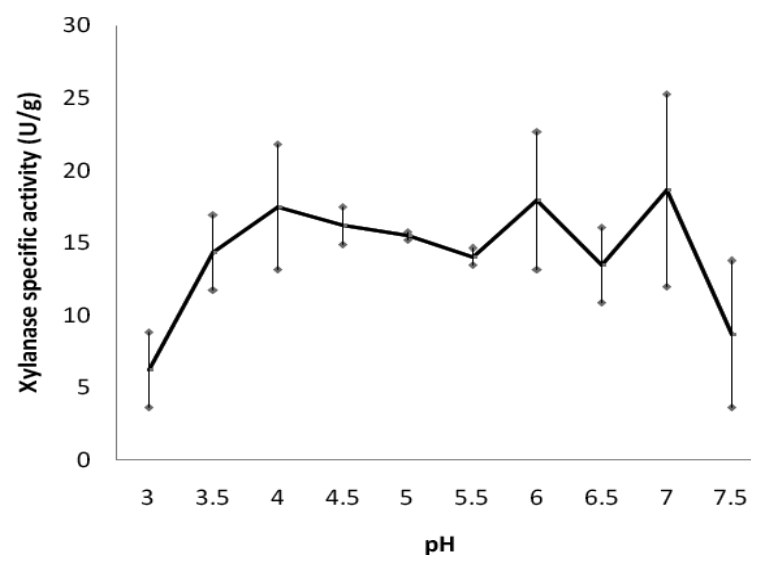

Figure 3. Influence of the $\mathrm{pH}$ on the activity of partially purified xylanase. For the $\mathrm{pH}$ profile, the enzyme activity was measured at room temperature in $50 \mathrm{mM}$ sodium phosphate and sodium actetate buffer adjusted to the correct $\mathrm{pH}$. Values are the means of results of duplicate experiments. Each point represents the mean of standard deviation (SD) (indicated by error bar) for two different enzymes.

Table 2. The effect of various carriers on xylanase activity

\begin{tabular}{lc}
\hline \multicolumn{1}{c}{ Type of carriers } & Xylanase activity $(\mathrm{U} / \mathrm{g})$ \\
\hline Corn & $46.80^{\mathrm{ab}} \pm 0.01$ \\
Tapioca & $60.30^{\mathrm{b}} \pm 3.27$ \\
Gaplek & $35.09^{\mathrm{a}} \pm 10.41$ \\
Soy bean meal & $28.30^{\mathrm{a}} \pm 3.18$ \\
\hline
\end{tabular}

$\mathrm{a}, \mathrm{b}$ significantly different $(\mathrm{P}<0.01)$ 
Hanim et al.

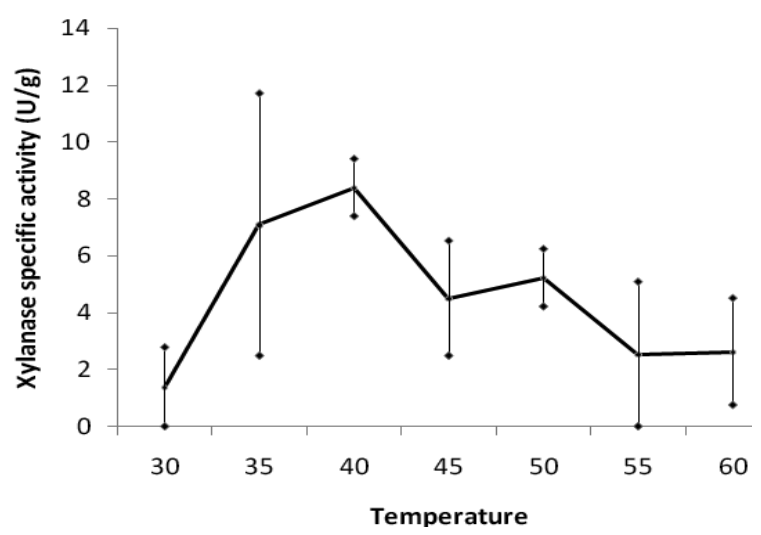

Figure 4. Influence of the temperature on the activity of partially purified xylanase. For the temperature profile, the enzyme activity was measured in $50 \mathrm{mM}$ sodium actetate buffer ( $\mathrm{pH}$ 6.0) at different temperatures. Values are the means of results of duplicate experiments. Each point represents the mean of standard deviation (SD) (indicated by error bar) for two different enzymes.

with tapioca as carrier $(60.30 \mathrm{U} / \mathrm{g})(\mathrm{P}<0.01)$, as presented in Table 2. Corn, gaplek and soy bean meal as carriers gave less xylanase activity, those were lower $22.39,41.81$, and $53.07 \%$ respectively than that tapioca.

\section{Discussion}

The solubility of a globular protein in an aqueous solvent is influenced by four main factors: salt concentration, $\mathrm{pH}$, the organic content of the solvent and the temperature (Palmer, 1991). Ammonium sulphate precipitation is an efficient method of lower mass xylanases. The material needed for the method is cheap, and finds much use in industrial purifications. Ammonium sulphate precipitation led to several fold purification such as 1.2 to 11-fold (Kuhar et al., 2007). Partially purified xylanase in the culture supernatant of Streptomyces galbus NR by salting out at 40-60 and 60-80\% ammonium sulphate saturation which led to the purification of 9.63 -fold and $68.80 \%$ recovery (Kansoh and Nagieb, 2004). In this study, $60 \%$ ammonium sulphate saturation led to the purification 3.15-fold and $89.40 \%$ recovery. In the enzyme purification steps, addition of a small amount of neutral salt to a solution increased the solubility of a
I.J. Biotech.

protein. The added ions changes ionization of amino acid side chains and can also interfere with interactions between protein molecules, the overall effect being to increase interactions between solute and solvent. At very high salt concentration, the abundance of interactions between the added ions and water decreases the possibilities for proteinwater interactions, often resulting in the protein being precipitated from solution (Palmer, 1991).

Xylanase secreted from xylanolytic alkalophylic bacteria had large molecular weight. Most xylanases are often found as monomeric protein with a molecular weight ranging from 11-80 kDa (Sunna et al., 1996). But xylanases of molecular weight as high as $537 \mathrm{kDa}$ (Matte and Forsberg, 1992), $350 \mathrm{kDa}$ (Shao et al., 1995), 340 kDa (Sa-Pereira et al., 2000), 212-253 kDa (Anthony et al., 2003), 150 kDa (Sunna et al., 1996), $150 \mathrm{kDa}$ (Khanna and Gauri, 1993), 140 kDa (Ito et al., 2003) 131 kDa (Touhy et al., 1993), $124.136 \mathrm{kDa}$ (Cazemier et al., 1999) have been also reported.

After the enzyme has beed recovered and concentrated, it is usually formulated in order to meet the product stability specifications suited to the application and handling practices employed by the end-user. Food-grade ingredients are required for food and feed applications. For solid products, the enzyme concentrate or formulated product, if suitable, can be granulated or dried in a manner that provides a solid product that meets health and safety requirements, such as low dusting (Clarkson et al., 2001). Most feed enzymes are supplied as liquid formulations at the end-user level, as these are convenient to use. It is mostly dry enzyme premixes that are being sold to the feed manufacturer. However, solid formulations can provide some significant advantages, such as enhanced stability, delayed or controlled release and protection against deactivation during harsh applications (Kuhar et al., 2007).

It could be concluded that the molecular masses of the xylanase were 137.61 and 
$165.34 \mathrm{kDa}$. Addition of $60 \%$ ammonium sulphate showed the highest xylanase activity (62.03 U/g) and $89.40 \%$ enzyme recovery. Tapioca, as a carrier, had the highest xylanase activity.

\section{References}

Anthony, T., Chandra, R.K., Rajendran, A., and Gunasekaran, P., 2003. High molecular weight cellulase-free xylanase from alkalitolerant Aspergillus fumigatus AR1. Enz. Microb.Technol, 32 (6), 647-654.

Cazemier, A.E., Verdoes, J.C., van Ooyen, A.J.J., and Op den Camp, H.J.M., 1999. Molecular and biochemical characterization of two xylanase-encoding genes from Cellulomonas pachnodae. Appl. Environ. Microbiol., 65 (9), 40994107.

Clarkson, K., Jones, B., Bott, R., Bower, B., Chotani, G., and Becker, T., (2001). Enzymes: screening, expression, design, and production. In Enzymes in farm animal nutrition. (M.R. Bedford and G.G. Partridge, eds.). CABI Pub. UK., 315-352.

Dalal, S., Sharma, A., and Gupta, M.N., 2007. A multipurpose immobilized biocatalyst with pectinase, xylanase and cellulase activities. Chemist. Cent. J., 1 (16), 1-6. doi:10.1186/1752-153X-1-16.

Dodd, D., and Cann, I.K.O., 2009. Enzymatic deconstruction of xylan for biofuel production. Global Change Biol. Bioener., 1, 2-17.

Dodd, D., Kocherginskaya, S.A., Spies, M.A., Beery, K.E., Abbas, C.A., Mackie, R.I., and Cann, I.K.O., 2009. Biochemical analysis of a $\beta$-D-xylosidase and a bifunctional xylanase-ferulic acid esterase from a xylanolytic gene cluster in Prevotella ruminicola 23. J. Bacteriol. 191 (10), 33283338, doi:10.1128/JB.01628-08.

Gupta, U., and Kar, R., 2009. Xylanase production by a thermo-tolerant Bacillus species under solid-state and submerged fermentation. Brazilian Arch. Biol. Technol., 52 (6), 1363-1371.
Hanim, C., Yusiati, L.M., Cahyanto, M.N., and Wibowo, A. 2013. Mutagenetic improvement of xyanase production from xylanolytic bacteria and its phylogenetic analysis. J. Microbiol. Ind., 7(1), (in press).

Ito, Y., Tomita, T., Roy, N., Nakano, A., Sugawara-Tomita, N., Watanabe, S., Okai, N., Abe, N., and Kamio., Y., 2003. Cloning, expression, and cell surface localization of Paenibacillus sp. strain W-61 xylanase 5, a multidomain xylanase. Appl. Environ. Microbiol., 69 (12), 6969-6978, doi: 10.1128/ AEM.69.12.6969-6978.2003.

Kansoh, A.L., and Nagieb, Z.A., 2004. Xylanase and mannanase enzymes from Streptomyces galbus NR and their use in biobleaching of softwood kraft pulp. Antonie van Leeuwenhoek, 85 (2), 103-114.

Khanna, S., and Gauri, 1993. Regulation, purification, and properties of xylanase from Cellulomonas fimi. Enz. Microb. Technol., 15 (1), 990-995.

Kuhar, K., Ninawe, S., Gupta, V.K., Kuhar, S., Tripathi, K.K., and Kuhad, R.C., (2007). Methods of purification and characterization of xylanases. In Lignocellulose biotechology future prospects. (R.C. Kuhad and A. Singh, eds.) I.K. Intl. Pub. House Pvt. Ltd. New Delhi, 165-187.

Matte, A., and Forsberg, C.W., 1992. Purification, characterization, and mode of action of endoxylanases 1 and 2 from Fibrobacter succinogenes S85. Appl. Environ. Microbiol., 58 (1), 157-168.

Palmer, T. (1991). Understanding enzymes. $3^{\text {th }}$ ed. Ellis Horwood Ltd. New York.

Pastor, F.I.J., Gallardo, O., Sanz-Aparicio, J., and Diaz, P., (2007). Xylanase: molecular properties and applications. In Industrial enzymes structure, function, and applications. (J. Polaina and A. P. MacCabe, eds.) Springer. Netherlands, 65-82

Plummer, D.T. (1978). An introduction to practical biochemistry. Tata Mc Graw Hill Publ. Co. Ltd. Bombay New Delhi. 
Rosner, B. (1990). Fundamentals of biostatistics. $3^{\text {rd }}$ ed. PWS-KENT Pub. Co., Boston, Massachusetts.

Ruiz-Arribas, A., Fernandaz-Abalos, J.M., Sanchez, P., Garda, A.L., and Santamaria, R.I., 1995. Overproduction, purification, and biochemical characterization of a xylanase (xys 1) from Streptomyces halstedii JM 8. Appl. Environ. Microbiol., 61 (6), 2414-2419.

Sá-Pereira, P., Duarte, J., and Costa-Ferreira, M., 2000. Electroelution as a simple and fast protein purification method: isolation of an extracellular xylanase from Bacillus sp. CCMI 966. Enz. Microb.Technol., 27 (1), 95-99.

Shao, W., Obi, S., Puls, J., and Wiegel, J., 1995. Purification and characterization of the (alpha)-glucuronidase from Thermoanaerobacterium sp. strain JW/ SL-YS485, an important enzyme for the utilization of substituted xylans. Appl. Environ. Microbiol., 61 (3), 1077-1081.

Singh, R. P., Dwivedi, P., Vivekanand, and Kapur, N., (2007). Xylanase: structure, molecular cloning and regulation of expression. In Lignocellulose biotechology future prospects. (R.C. Kuhad and A. Singh, eds.) I.K. Intl. Pub. House Pvt. Ltd. New Delhi, 149-161.

Skinner, F.A. (1971). Isolation of soil Clostridia. In Isolation of anaerobes. The Society for Applied Bacteriology Technical Series No. 5. Academic Press, London, New York.

Sunna, A., Puls, J., and Antranikian, G., 1996. Purification and characterization of two thermostable endo- $\beta-1,4-x y l a n a s e s$ from Thermotoga thermarum. Biotech. Appl. Biochem., 24 (2), 177-185.

Taylor, E.J., Smith, N.L., Turkenburg, J.P., D'Souza, S., Gilbert, H.J., and Davies, G.J., 2006. Structural insight into the ligand specificity of a thermostable family 51 arabinofuranosidase, Araf 51, from Clostridium thermocellum. J. Biochem., 395, 31-37, doi:10.1042/BJ20051780.
Tuohy, M. G., Puls, J., Claeyssens, M., Vrsanskas, M., and Coughlan, M.P., 1993. The xylan-degrading enzyme system of Talaromyces emersonil: novel enzymes with activity against aryl f-D-xylosides and unsubstituted xylans. J. Biochem., 290, (2), 515-523. 